International Journal of Current Microbiology and Applied Sciences

ISSN: 2319-7706 Volume 9 Number 4 (2020)

Journal homepage: http://www.ijcmas.com

Original Research Article

https://doi.org/10.20546/ijcmas.2020.904.212

\title{
A Field Study on Prevalence of Subclinical Mastitis in Indigenous Kangayam Cows
}

\author{
S. Manokaran ${ }^{1 *}$, N. V. Kavithaa ${ }^{1}$ and T. Geetha ${ }^{2}$ \\ ${ }^{1}$ Kangayam Cattle Research Station, Uppupallam, Baguthampalayam, \\ Sathyamangalam - 638 451, India \\ ${ }^{2}$ Veterinary University and Training Centre, Veterinary Hospital campus, Kamarajarsalai, \\ Tiruppur - 648 604, India \\ *Corresponding author
}

\section{Keywords}

Kangayam cows, Subclinical mastitis, CMT kit, Incidence, Risk factors

\section{Article Info}

Accepted:

15 March 2020

Available Online:

10 April 2020
The present study was conducted to assess the prevalence of subclinical mastitis in Kangayam cows. The study was conducted in three districts of Tamil Nadu at farmer's field. For diagnosis of subclinical mastitis (SCM) in Kangayam animals California Mastitis Test (CMT) was done. An incidence of $43 \%$ of SCM was recorded in Kanagaym animals out of 100 animals studied. The quarter wise prevalence showed an incidence of $20.50 \%$. Study on the individual quarters indicated 23.17, 29.16, 20.73 and $26.82 \%$ incidence in right fore, right hind, left fore and left hind quarters, respectively. The incidence of SCM is more in adult animals $(52.54 \%)$ than young animals (29.27\%). The incidence was higher (56.67\%) in 7 and above lactation than $4-6^{\text {th }}$ lactation $(45.45 \%)$ and $1-3^{\text {rd }}$ lactation $(29.73 \%)$. The mid lactation stage $(50.00 \%)$ cows were affected more followed by early lactation (40.81\%) and late lactation (36.81\%) stages.

\section{Introduction}

In dairy industry, subclinical mastitis (SCM) is a more serious issue and is responsible for greater loss (Kader et al., 2002). In SCM, there are no gross inflammatory changes in the udder tissue. According to Singh and Singh (1994), the loss due to SCM is three times higher than the loss caused by clinical mastitis (CM). Further, the animals affected with SCM remain as a continuous source of infection to their herd mates. Studies have reported that the incidence of sub clinical mastitis ranged from 19.20 to $83 \%$ in cows. In India, about $70-80 \%$ economic loss has been attributed due to sub clinical mastitis alone 
(Dua, 2001). Sinha et al., (2014) reported an overall loss due to SCM wasRs. 1592.87 per animal per lactation in crossbred animals. The reports on the subclinical mastitis in the indigenous animals are limited due to their less population, distribution and absence of organized farms. Devi et al., (1997) reported an incidence of $57.35,75.00$ and $80.00 \%$ SCM in Malvi, Sahiwal and Gir breeds in Madhya Pradesh. Kangayam breed is distributed in the farmer's field of in Tiruppur, Erode, Karur districts and also in Coimbatore, Dindugul districts of Tamil Nadu. Similar studies on the incidence of SCM in Kangayam cows are scarce. Hence the present study was conducted to document the prevalence of SCM in Kanagaym cows under field conditions.

\section{Materials and Methods}

The study was conducted in 100 Kangayam cows in the farmer's field at Erode, Tiruppur and Karur Districts of Tamil Nadu. The animals were selected randomly. A total of 400 milk samples collected from 100 Kangayam cows were analysed for SCM by using California Mastitis Test (CMT kit) (Schalm and Noorlander, 1957). The study was conducted during morning milking. The plastic paddle with four shallow cups of the CMT kit was marked as left fore (LF), left hind $(\mathrm{LH})$, rightfore $(\mathrm{RF})$ and right hind $(\mathrm{RH})$ to test the individual quarter wise incidence of SCM. The udder of the animal was washed and the first strip of milk from the udder was discarded. The next strip of the milk was collected in the respective shallow cups of the paddle. Approximately 2-3 $\mathrm{ml}$ of milk was taken in each cup. The equal quantity of the CMT reagent was added in each cup of the paddle without making air bubbles. It was mixed gently by circular movement in horizontal plane for 5-10 seconds. The observation was made within 30 seconds after mixing for formation of viscous gel and the score was given. Based on the gel formation, the CMT score was given as strong positive $(+++)$, distinct positive $(++)$, weak $(+)$ and negative (Normal) as described by Lahamg et al., (2019). The data regarding subclinical mastitis of each individual quarter was recorded on a data sheet.

\section{Results and Discussion}

The overall incidence and quarter wise prevalence of SCM in Kangayam animals is given in Table 1.

The overall incidence of $43 \%$ (43 out of 100 animals) of SCM was recorded in Kangayam animals under field condition in this study. The observation was in accordance with the observations made by Khanal and Pandit (2013) (46.1\%) and Swami et al., (2017) (35\%) whereas a higher incidence was recorded by Lahamge et al., (2019) (70.19\%). According to Varshney and Naresh (2004), the prevalence of SCM was varying from 10$50 \%$ in cows and $5-20 \%$ in buffaloes when compared to clinical mastitis (1-10\%). Payne and Wilson (1999) reported that in general the incidence of SCM in indigenous cows was lower than crossbred cows and he opined that the highest resistance in native breeds due to their genetic resistance and adaptation of these animals to native environment and climate might be the reason for the lower incidence.

The quarter wise prevalence of SCM in Kangayam cows using CMT kit showed an incidence of $20.50 \%$ ( 82 out of 400). In the 82 affected quarters, 19 (23.17\%), 24 (29.16\%), $17(20.73 \%)$ and $22(26.82 \%)$ were right fore, right hind, left fore and left hind quarters, respectively. The observations indicated that right side [right fore $(23.17 \%)$ and right hind $(29.16 \%)]$ quarters were affected more with SCM than left side [left fore $(20.73 \%)$ and left hind $(26.82 \%)$ ] quarters. The higher incidence 
of SCM in right side quarters could be due to the fact that the cows more frequently sit on the right side with the result that these quarters were exposed to dung and soil and also might be due to pressure exerted by the body of the animal on the udder (Rupakala, 2016). The current study also indicated that the hind quarters $(29.16 \%$ and $26.82 \%)$ are affected more than fore quarters $(23.17 \%$ and 20.73\%). Singh et al., (2010) observed that the incidence of subclinical mastitis was higher in hind quarters (67.92\%) when compared to fore quarters $(32.56 \%)$ and he opined that the higher incidence in hind quarters could be attributed to greater exposure of the hind quarters to contamination with dung and urine.

Khan and Mohammed (2005) reported 36\% (72 out of 200) quarters were affected by SCM which included 14 (19.40\%) right fore, $20(27.80 \%)$ right hind, $13(18.10 \%)$ left fore and $25(34.70 \%)$ left hind quarter. In another study, Swamy et al., (2019) recorded $18.25 \%$ (45 out of 240) quarters were affected which included 11 (24.44\%) right fore, 13 (29.54\%) right hind, $9(20.45 \%)$ left fore and 12 $(27.27 \%)$ left hind quarter. Both these studies were in accordance with the observations made in this study. In contrast to this study, Khanal and Pandit (2013) reported that SCM was highest in left fore quarter $(34.92 \%)$ followed by left hind $(31.76 \%)$, right hind $(28.57 \%)$ and right fore $(25.39 \%)$ quarters.

The association between the various factors (age, No. of lactation and stage of lactation) on the prevalence of SCM was studied and is presented in Table 2. The results indicated that the incidence of SCM is more in adult animals (52.54\%) than young animals (29.27\%). Similar to this study, Barmendra et al., (2011) reported that the prevalence of SCM was highest in aged group of 9-10 years $(52.80 \%)$ and least in 3-4 year group $(33.30 \%)$.

The observations on the number of lactation on the prevalence of SCM indicated that incidence was higher (56.67\%) in 7 and above lactation followed by 4-6 lactation $(45.45 \%)$ and 1-3 lactation (29.73\%). Patel et al., (2000) documented that prevalence of SCM was highest during $7^{\text {th }}$ lactation $(42.85 \%)$ and moderate during $3-5^{\text {th }}$ lactation $(33-36 \%)$. The gradual loss in the immune system of the body of the animal with increase in the lactation number makes the susceptibility for infection. Further the median ligaments which provide support to the teat also get relaxed with increasing age leading to hanging of udder and making it more prone to mastitis.

Table.1 Overall and quarter wise incidence of SCM in Kangayam cows

\begin{tabular}{|c|c|c|c|c|c|c|c|c|}
\hline \multirow[t]{2}{*}{ Breed } & \multicolumn{2}{|c|}{$\begin{array}{l}\text { No. of animals } \\
(\%)\end{array}$} & \multicolumn{2}{|c|}{$\begin{array}{c}\text { Quarter wise } \\
\text { affected animals } \\
\text { in total }(\%)\end{array}$} & \multicolumn{4}{|c|}{$\begin{array}{c}\text { Individual quarter wise affected } \\
(\%)\end{array}$} \\
\hline & Tested & Positive & Tested & Positive & RF & RH & LF & LH \\
\hline $\begin{array}{l}\text { Kangayam } \\
\text { cow }\end{array}$ & 100 & $\begin{array}{c}43 \\
(43.00)\end{array}$ & 400 & $\begin{array}{c}82 \\
(20.50)\end{array}$ & $\begin{array}{c}19 \\
(23.17)\end{array}$ & $\begin{array}{c}24 \\
(29.16)\end{array}$ & $\begin{array}{c}17 \\
(20.73)\end{array}$ & $\begin{array}{c}22 \\
(26.82)\end{array}$ \\
\hline
\end{tabular}


Table.2 Association between various factors with the occurrence of SCM in Kangayam cows

\begin{tabular}{|l|l|c|c|}
\hline \multicolumn{2}{|c|}{ Factors studied } & $\begin{array}{c}\text { Total } \\
\text { animals } \\
\text { tested }\end{array}$ & $\begin{array}{c}\text { Affected animals } \\
(\%)\end{array}$ \\
\hline Age & Young & 41 & $12(29.27)$ \\
\cline { 2 - 4 } & Adult & 59 & $31(52.54)$ \\
\hline \multirow{2}{*}{ No. of Lactation } & $1-3$ & 37 & $11(29.73)$ \\
\cline { 2 - 4 } & $4-6$ & 33 & $15(45.45)$ \\
\hline \multirow{2}{*}{ Stage of lactation } & 7 and above & 30 & $17(56.67)$ \\
& Early & 49 & $20(40.81)$ \\
\cline { 2 - 4 } & Mid & 32 & $16(50.00)$ \\
\cline { 2 - 4 } & Late & 19 & $7(36.84)$ \\
\hline
\end{tabular}

(Young: <6 years and adult: $>6$ years; Early lactation: 1 to 60 days, mid lactation: 61 to 120 days and late lactation: $>120$ days)

In this study, the incidence of SCM was higher in mid lactation stage $(50.00 \%)$ followed by early lactation $(40.81 \%)$ and late lactation $(36.81 \%)$ stages in Kangayam cows.

These observations were in accordance with the observations made by Swami et al., (2017).

The risk factors such as host (breed, yield, age, parity, stage of lactation, udder confirmation, udder defense, interval between milking, somatic cell count, dry period, injuries on teat and udder, genetic resistance), microorganisms causing SCM (virulence factor and number of organisms), management practices (hygiene of farm and animal, environment, number of animals maintained, milking technique, milking machine hygiene, teat dipping), diet (copper, cobalt, zinc, selenium and vitamin $\mathrm{E}$ deficiency) were having some effect on the occurrence of SCM (Kumari et al., 2018).

From the study it is concluded that (i). The incidence of SCM in Kangayam cows is $43.00 \%$, (ii). The right side quarters are affected more with SCM than left side quarters, (iii). The prevalence of SCM was found more in hind quarters than fore quarters in Kangayam cows and (iv). Age, number of lactation and stage of lactation are some of the factors have effect on the prevalence of SCM in Kangayam cows.

\section{References}

Barmendra, S., Rahman, M.S.U., Hannan, M.A., Rahman, M.M., Bhuiyan, M.M. and Bari, F.Y. 2011.Prevalence of mastitis in dairy cows in selected areas of Bangladesh. International J. Biores., 1: 5-9.

Devi, B.K., Shukla, P.C. and Bagherwal, R.K.1997. Incidence of subclinical mastitis in cows. Indian Journal of Dairy Science, 50: 477-478.

Dua, K., 2002. Incidence, etiology and estimated economic losses due to mastitis in Punjab and in India- An update. Indian Dairyman, 53: 41-48.

Kader, M. A., Samadand, M. A., and Saha, S. 2003. Influence of host level factors on prevalence and economics of subclinical mastitis in dairy cows in Bangladesh. Indian Journal of Dairy Science, 56: 235-240.

Khan, A.Z., and Muhammad, G. 2005. Quarter-wise comparative prevalence of mastitis in buffaloes and crossbred 
cows. Pakistan Vet. J., 25: 9-12.

Khanal, T., and Pandit, A. 2013. Assessment of sub-clinical mastitis and its associated risk factors in dairy livestock of Lamjung, Nepal. International J. Infec. Micobiol., 2: 49-54.

Kumari, T., C. Bhakat and Choudhary, R.K. 2018. A review on sub clinical mastitis in dairy cattle. International J. Pure App. Biosci., 6: 1291-1299.

Lahamge, M.S., A. Thakre, S.W. Bonde, S.D. Borkar, A.P. Somkuwar and Patil, D.V. 2019. Prevalence of Subclinical Mastitis in Cows: In and Around Nagpur Region. International J. Cur. Microbiol. App. Sci., 8: 83-88.

Patel, P.R., S.K. Raval, N.Rao, G.C. Mandali and Jani, R.G. 2000.Status of mastitis in Gujarat State. Proceedings of the Round Table Conference of the Indian Association for the Advancement of Veterinary Research (IAAVR) on Mastitis, IVRI, Izatnagar, India, pp: 4552.

Payne, W.J.A., and Wilson, R.T. 1999. An introduction to Animal Husbandry in the Tropics. $5^{\text {th }}$ edn., Blackwell Publishing Ltd, Iowa State University Press, USA. pp: 826.

Rupakala, S., 2016.Studies on diagnosis and therapy of subclinical mastitis in buffaloes. M.V.Sc thesis submitted to
NTR College of Veterinary Science, Sri Venkateswara Veterinary University, Tirupati.

Schalm, O.W., and Noorlander, D.O. 1957. Experiments and observations leading to developments of California Mastitis Test. J. American Vet. Med. Assoc., 130: 199-204.

Singh, B., M.L.V. Rao, D.K. Gupta, N.K. Jain and Shukla, P.C. 2010. Epidemiological studies of subclinical mastitis in different organized dairy farms. Jawaharlal Nehru Krishi Vishwa Vidyalaya Res. J., 44: 221-222.

Singh, P.J., and Singh, K.B. 1994. A study of economic losses due to mastitis in India. Indian J. Dairy Sci., 47:265-272.

Sinha, M.K., N.N. Thombare and Mondal, B. 2014. Subclinical mastitis in dairy animals: Incidence, economics and predisposing factors. Scientific World Journal, 1-4 (Article ID 523984)

Swami, S.V., R.A. Patil and Gadekar, S.D. 2017.Studies on prevalence of subclinical mastitis in dairy animals. J. Entamol. Zool. Stud., 5: 1297-1300.

Varshney, J.P., and Naresh, R. (2004).Evaluation of homeopathic complex in the clinical management of udder diseases of riverine buffaloes. Homeopathy, 93: 17-20.

\section{How to cite this article:}

Manokaran, S., N. V. Kavithaa and Geetha, T. 2020. A Field Study on Prevalence of Subclinical Mastitis in Indigenous Kangayam Cows. Int.J.Curr.Microbiol.App.Sci. 9(04): 1809-1813. doi: https://doi.org/10.20546/ijcmas.2020.904.212 